\title{
Aika, paikka ja historia Papua-Uuden-Guinean mengenien ympäristössä
}

\section{Tammisto, Tuomas}

University of Helsinki, Department of Social Research

2012

Tammisto , T 2012 , Aika, paikka ja historia Papua-Uuden-Guinean mengenien ympäristössä . julkaisussa T Kallinen , A Nygren \& T Tammisto (toim) , Ympäristö ja kulttuuri . Sosiaalitieteiden laitoksen julkaisuja, Nro 2012:11, University of Helsinki, Department of Social Research, Helsinki, Sivut 470 . < https://helda.helsinki.fi/handle/10138/35717 >

http://hdl.handle.net/10138/166418

cc_by_nd

publishedVersion

Downloaded from Helda, University of Helsinki institutional repository.

This is an electronic reprint of the original article.

This reprint may differ from the original in pagination and typographic detail.

Please cite the original version. 


\section{Aika, paikka ja historia Papua-Uuden- Guinean mengenien ympäristössä}

Tuomas Tammisto

\section{Johdanto}

Kulkiessani kenttätyöni aikana kahden ystäväni kanssa sademetsässä panin merkille kuinka tottuneesti ja varmasti he liikkuvat siellä. Ystäväni olivat koirineen metsästämässä villisikoja ja päättivät samalla näyttää minulle paikkoja. Noustuamme matalalle vuorelle eteemme avautui metsäautotie, jonka kasvit olivat vallanneet. Ystäväni kertoivat, että tien oli rakentanut malesialainen metsäyhtiö hakkuiden yhteydessä. Tie kuitenkin tunkeutui alueelle, jota hallinnoiva klaani ei hyväksynyt hakkuita, ja pian tien rakentamisen jälkeen paikalliset maata omistavat klaanit ajautuivat kiistaan kyseisen alueen omistuksesta. Lopulta kiista ratkesi oikeudessa, hakkuita vastustanut klaani todettiin alueen omistajaksi ja metsäyhtiö vetäytyi jättäen tienpätkän jälkeensä. Itselleni soratie oli hyvin tunnistettava ja helposti hahmotettavaa ympäristöä ja siksi yllätyin kun ystäväni eksyivät miltei heti saavuttuamme tielle. Kierreltyämme hetken metsässä, toinen heistä löysi oikean suunnan ja kertoi, että tie oli pyyhkinyt altaan polkuja, joita pitkin hän oli tottunut kulkemaan. Hänen mukaansa paikka oli 
muuttunut niin tunnistamattomaksi, etteivät edes polut tallanneet esivanhemmat pystyisi enää kulkemaan alueella eksymättä. ${ }^{1}$

Tämä melko arkinen tapaus on hyvä osoitus siitä miten eri asiat ympäristössä ovat merkityksellisiä ja kuinka Uuden-Britannian saaren itäosissa asuville sulkille ja mengeneille ${ }^{2}$ aika, paikka ja historia ovat tiiviisti kietoutuneita toisiinsa. Ympäristöön liitetyt merkitykset muuttuvat ja ovat uhattuina hakkuiden, teiden ja "taloudellisen kehityksen" myötä. Wide Bayn alue Uuden-Britannian saaren itärannikolla sijaitsee vain 150 kilometrin päässä Itä-Uuden-Britannian maakuntapääkaupungista Rabaulista - yhdestä Papua-Uuden-Guinean vilkkaimmasta ja vanhimmasta kaupungista. Tästä huolimatta alue on maantieteellisesti varsin eristynyt, sillä Uuden-Britannian tieverkosto ei yllä Wide Bayhin asti ja alueelle pääsee vain veneellä. Maantieteellisestä eristyneisyydestään huolimatta Wide Bay ei missään nimessä ole koskematon alue: sulkat ja mengenit liikkuvat töiden ja opiskelujen perässä, palaavat takaisin kotiseuduilleen ja ovat hyvin tietoisia maailman tapahtumista. Vastaavasti malesialaiset metsäyhtiöt, kuten Rimbunan Hijau alihankkijoineen, ovat suorittaneet laajamittaisia kaupallisia hakkuita Uuden-Britannian syrjäisissä osissa 1980-luvulta lähtien. Myös mengenien ja sulkien alueita on hakattu, paikallisten maanomistajien luvalla, ja hakkuiden perintönä alueella on kirjo metsäautoteitä, jotka eivät kuitenkaan ole yh-

1 Artikkeli perustuu vuonna 2007 Wide Bayn alueella sijaitsevassa pienessä ja pääosin mengenien asuttamassa kylässä tehtyyn kolmen kuukauden mittaiseen kenttätyöhön.

2 Noin 4000 puhujan sulka ja 8000 puhujan mengen muodostavat kaksi erillistä etnistä ja kieliryhmää, mutta ovat silti tiiviissä suhteessa keskenään. Keskinäiset avioliitot ovat yleisiä ja kummankin ryhmän sosiaalinen rakenne perustuu äidin linjan mukaan laskettaviin klaaneihin ja kahteen puoliskoon, johon klaanit jakautuvat. Sulkien ja mengenien klaanit vastaavat asukkaiden mukaan myös toisiaan, vaikka ovatkin erillisiä klaanien omistamien maa-alueiden ja johtajien suhteen. Kielellisesti papualaisiin kieliin kuuluva sulka ja austronesialainen mengen eivät ole sukua tai keskenään ymmärrettäviä, vaikka sulka onkin lainannut useita piirteitä austronesialaisista kielistä (Gordon 2005; Reesink 2005). 
teydessä maakuntapääkaupungin ympäristön kattavaan kansalliseen tieverkostoon - tai juuri mihinkään muuhunkaan.

Niin alueen asukkaiden kuin paikallisten poliitikkojenkin mukaan tieyhteyden puute maakuntapääkaupunkiin on pääasiallinen este taloudelliselle kehitykselle. Kiertävästä kaskiviljelystä elantonsa saavat sulkat ja mengenit ovat omavaraisia ruoan ja asumisen suhteen, mutta eivät silti irrallaan rahataloudesta. Päinvastoin - koulutus, terveydenhuolto, liikkuminen ja tarve-esineet alkaen kaskitaloudessa käytettävistä viidakkoveitsistä ja kirveistä vaativat rahaa. Monet paikalliset omavarasviljelijät harjoittavat myös pienimuotoista rahakasvien, kuten kaakaon, viljelyä. Puutteellisen infrastruktuurin vuoksi satoa on hankala saada keskuksiin myytäväksi ja se ehtii osin pilaantua epäsäännöllisiä laivakuljetuksia odotellessa. Taloudellisen kehityksen vauhdittamiseksi paikallinen kansanedustaja ja PapuaUuden-Guinean hallituksen ministeri, Paul Tiensten on aloittanut kehityshankkeen, jonka tarkoituksena on lisätä hakkuita alueella. Vastineeksi paikallisilta saaduista hakkuuoikeuksista metsäyhtiöt lupautuvat yhdistämään jo olemassa olevat metsäautotiet kansalliseen tieverkostoon. Hakkuiden lisäksi myös rahakasvien kasvatusta alueella tulisi lisätä, ja hankkeeseen kuuluu niin laajoja kuin paikallistenkin viljelemiä pienempiä öljypalmuplantaaseja.

Kirjoittamisajankohtana kyseistä hanketta ei ole vielä toteutettu, mutta sen kannatus vaikuttaa olevan laaja Itä-Uuden-Britannian syrjäseutujen asukkaiden keskuudessa. Vuonna 2007 Paul Tiensten valittiin jatkokaudelle maan parlamenttiin pitkälti taloudelliseen kehitykseen perustuvan kampanjansa ansiosta. Kysymys taloudellisen kehityksen vauhdittamisesta luonnonvarojen käytön lisäämisellä ja öljypalmuplantaaseja perustamalla ei kuitenkaan ole yksioikoinen. Niin kansalliset kuin kansainvälisetkin luonnonsuojelujärjestöt ovat varoittaneet öljypalmuplantaasien haitallisista seurauksista. Vastaavasti osa sulkien ja mengenien maata omistavista klaaneista vastustaa hakkuita alueillaan. Sulkien ja mengenien ympäristö ei koostu vain hallinnoitavista ja hyödynnettävistä resursseista, jotka ovat yritysten pääasiallisen mielenkiinnon kohteena. Ympäristöön liitetään 
ja se pitää sisällään laajan kirjon kulttuurisia merkityksiä, jotka eivät palaudu - kieltämättä erittäin tärkeisiin — taloudellisiin kysymyksiin. Aika, historia ja ympäristö ovat tiiviisti toisiinsa kietoutuneina sulkien ja mengenien ympäristössä. Niin yksittäisten ihmisten kuin klaanienkin historiat aineellistuvat ympäristössä, jossa nimetyt paikat ovat osa klaanien alkuperätarinoita. Nämä tarinat muuttuvat uudella tavalla kiinnostaviksi maanomistusta ja -käyttöä koskevissa kysymyksissä, joita alueelle ehdotetut hakkuut tuovat mukanaan.

\section{Kaskiviljely ja ajan jaksottaminen}

Mengenien ja sulkien harjoittamassa kaskiviljelyssä raivataan kaskipalstoja tai -puutarhoja metsään, niitä hoidetaan vuoden verran, minkä jälkeen palstat jätetään taas metsittymään. Maa on äidin linjan mukaan sukua laskevien klaanien yhteisomistuksessa. Toisin sanoen yksittäinen klaani tai klaanin suurempi alajaosto omistaa tai pikemminkin hallinnoi tiettyä maa-aluetta. Olennaista omistuksen kannalta on, että myös muut klaanit tunnustavat sen. Kahteen puoliskoon jakautuvat klaanit ovat niin puoliskon kuin klaaninkin tasolla tiukan eksogaamisia, eli omaan puoliskoon tai klaaniin kuuluvan henkilön kanssa ei saa avioitua. Siten harva asuu oman klaaninsa hallinnoimalla maa-alueella, minkä vuoksi maankäyttöoikeus on käytännössä kaskitalouden kannalta tärkeämpää kuin varsinainen omistus. Esimerkiksi vaikka tietty kylä sijaitseekin yhden klaanin omistamalla alueella, saavat (lukuisiin eri klaaneihin) kuuluvat kylän asukkaat oletusarvoisesti raivata palstojaan alueelle ilman erillistä lupaa. Maankäyttöoikeudet ovatkin joustavia ja ne periytyvät usein perhesuhteiden myötä ilman maata omistavan klaanin erityistä väliintuloa.

Kaskitalous on ensiarvoisen tärkeää, sillä sen turvin mengenit ovat käytännössä omavaraisia ruoan suhteen. Tämän lisäksi kaskitaloudella on monia muita merkityksiä mengeneille. Kuvatessaan 1960-luvun mengenien kaskiviljelyä, Francoise Panoff $(1969,22)$ 


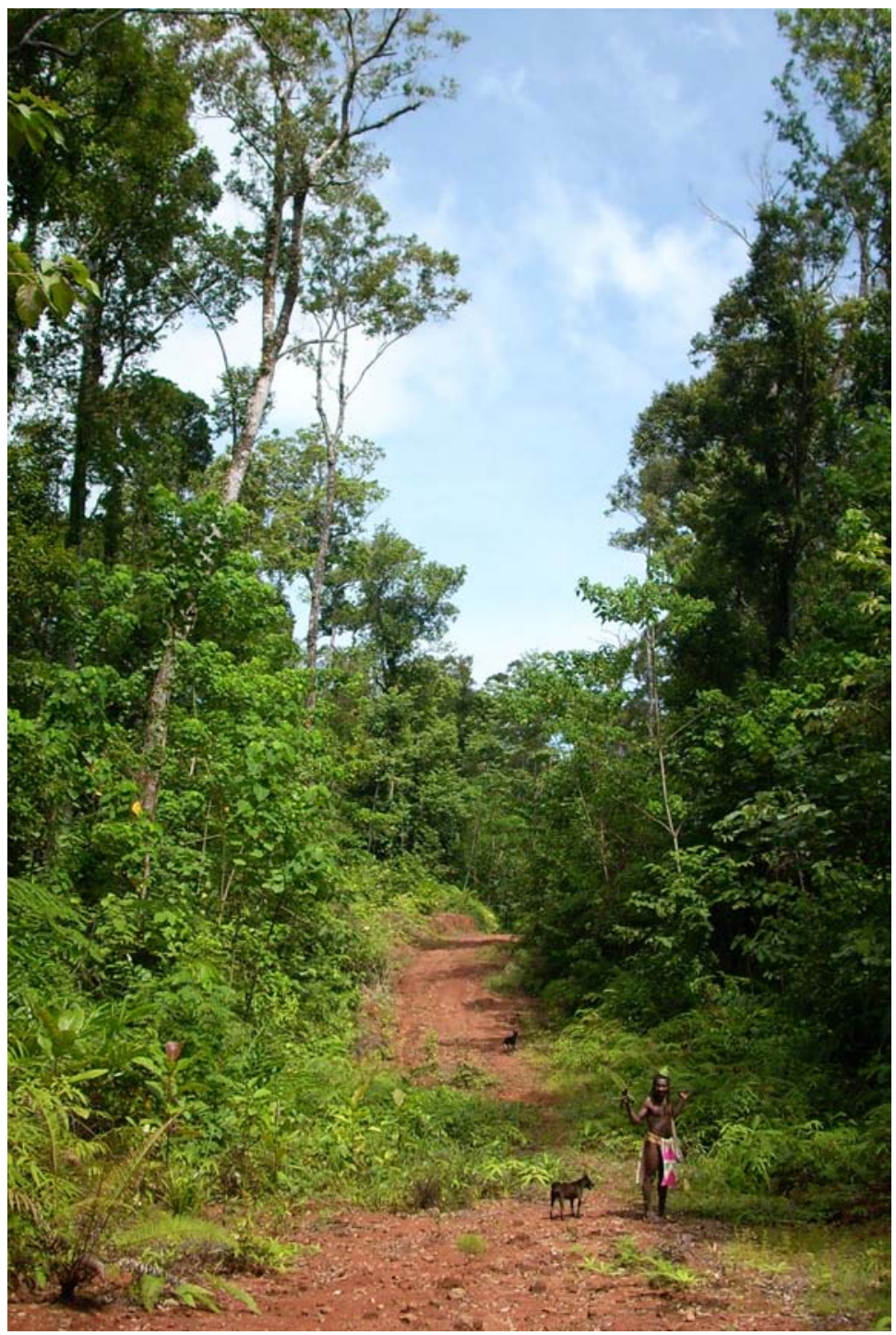

Kuva 1. Primäärimetsään hakkuiden yhteydessä raivattu metsäautotie. Metsästämässä oleva mies on poikkeuksellisesti pukeutunut perinnelannevaatteeseen (Tuomas Tammisto). 
huomauttaa, että runsasta ja hyvin kasvavaa kaskipalstaa pidettiin kauniina, ja että uuden tai harvinaisen kasvilajin kasvattaminen oli älyllinen haaste ja siten jo itsessään arvokasta. Oman kokemukseni mukaan Panoffin kuvaus pätee nykyäänkin. Mengenit tuntevat ja osaavat nimetä vaikuttavan määrän niin villejä kuin kesyjäkin kasveja. Kulkiessani sademetsässä mengen-ystävieni kanssa keräsivät he jatkuvasti kasveja kylään istutettavaksi. Uusien lajikkeiden kasvattamista kokeillaan esimerkiksi pienemmillä palstoilla puhtaasti mielenkiinnosta ja huvin vuoksi. Panoffin $(1969,22)$ mukaan pääviljelykasvilla tarolla (Colocasia esculenta) katsottiin olevan sielu — aivan kuten ihmisilläkin — ja juuri tämä tekee siitä ravitsevan. Vastaavasti villeillä kasveilla ei ole sielua ennen kuin ne "kesytetään", eli otetaan hoitoon. Näin kaskipalstan viljely vertautuu myös lasten kasvattamiseen ja hoitamiseen, mikä on melko yleinen analogia Uuden-Guinean kaskiviljelijöiden parissa (ks. esim. Bashkow 2006; Fajans 1998).

Trooppisen ilmaston vuosi jakautuu kahteen yhtä pitkään kauteen, eli sade- ja kuivaan kauteen, jotka hallitsevat mengenien asuttamaa ympäristöä. Nämä kaudet määrittävät kaskitalouden vuotuista rytmiä, sillä sadekauden aikana valtaosaa kasveista ei voida istuttaa, kun taas kuivan kauden huippuun sijoittuu muun muassa taron sadonkorjuu ja vuotuiset rituaalit, jotka ajoitetaan sadonkorjuun mukaan. Vaikka vuoden kiertoa leimaakin kaksi kautta, joiden mukaan rituaalit ja kasvien istutus ajoitetaan, on mengenien ajanlaskutapa ja viljelyjärjestelmä huomattavasti hienostuneempi. Jako sade- ja kuivaan kauteen on karkein tapa jaksottaa aikaa, sillä viljelyyn liittyvät toimenpiteet ajoitetaan niin sanotun puu- tai kyläkalenterin (tok pisin: kalender bilong ples) mukaan. Tämä järjestelmä jaksottaa vuoden 12 kuukauden ja tiettyjen "indikaattoripuiden" vaiheiden mukaan (Panoff M. 1969, 159). Näiden puiden kukkimisen, lehtien putoamisen ja kasvamisen mukaan ajoitetaan eri viljelyskasvien istuttaminen, sadonkorjuu, kaskipalstojen raivaaminen ja hoitaminen. Minulle kerrottiin, että onnistuneen sadon saamiseksi kaskipalstan hoitaminen on ajoitettava tämän kalenterin mukaisesti. Michel Panoffin 
1960-luvulla dokumentoima järjestelmä on edelleenkin käytössä ja minulle opetettiin tämän kalenterin paikallisesti systematisoitu versio kenttätyöni aikana. Lähikylien vanhukset olivat kokoontuneet yhteen kirjatakseen perimätiedon ylös, jotta kalenteria voitaisiin opettaa kyläkouluissa lapsille. Tämä liittyi vuonna 2000 tehtyyn valtakunnalliseen opetusuudistukseen, jossa koulu aloitetaan englannin sijasta paikallisella kielellä ja paikallisten tapojen ja perinteiden opettamista koulussa painotetaan.

Michel Panoffin $(1969,159)$ näkemys, jonka mukaan mengenit jaottelevat aikaa ekologian, eikä niinkään ekologiaa ajan mukaan, tuntuu uskottavalta. Tätä tukee niin sanotun kyläkalenterin käyttö, kuten myös se, että puiden kasvua käytetään yleisemminkin ajan hahmottamiseen. Kenttätyöni aikana haastattelin vanhempaa miestä kylän historiaan liittyen, ja hän käytti kookospalmujen kasvua muistellakseen kuinka kauan kyläläiset olivat taisteluja paossa metsässä toisen maailmansodan aikana:

Sota alkoi ja me pakenimme metsään. Sanoisin, että olimme siellä noin kolme vuotta, sillä kun palasimme, olivat istuttamamme kookospähkinät valmiita kantamaan hedelmää. - mies, noin 70 vuotta

Sen lisäksi, että puita käytetään ajan laskemiseen ja kasvukausien käsitteellistämiseen, puu on mengeneille myös historian symboli. Tämän kaltainen "kasvimetafora, joka yhdistää kasvun ja periytymisen" on James Foxin $(2006,8)$ mukaan hyvin tyypillinen austronesialaisille kansoille, joihin mengenitkin lukeutuvat. Michel Panoff $(1969,164)$ toteaa, että mengenit vertaavat historiaa puun kasvuun, sillä puun kasvun tavoin historia etenee ja on samalla peruuttamatonta: tapahtumat ovat kuin yksittäisten oksien kuihtumisia. Vastaavasti, kuten minulle kerrottiin, klaanit ovat kuin puita ja niiden alajaostot oksia. Tähän liittyi myös tietty peruuttamattomuus, sillä kuulin lukuisia tarinoita alajaostojen eroamisesta klaanista, mutta kuten Panoff $(1969,164)$ huomauttaa, tarinoita alajaostojen liittymisestä takaisin emäklaaniinsa ei kerrota. 


\section{Merkitty ja merkityksellinen ympäristö}

Mengeneille aika ja ympäristö ovat siis tiiviissä käsitteellisessä yhteydessä toisiinsa. Ekologisten ilmiöiden avulla jäsennetään aikaa, puiden avulla vuosi jaetaan maanviljelyksen kannalta tärkeisiin kausiin ja puu on vertauskuva mengenien käsitykselle historiasta. Tämän lisäksi ympäristö hyvin konkreettisella edustaa, dokumentoi ja itse asiassa on historiaa. Stuart Kirschin $(2006,11)$ mukaan keskisessä Uudessa-Guineassa asuville yonggomeille yksittäisen ihmisen elämäntarina näkyy ympäristössä tunnistettavissa inhimillisen työn merkeissä, joita esimerkiksi puiden kaataminen tai kaskipalstan raivaaminen jättää jälkeensä. Tämän vuoksi maisema pitää sisällään muistoja menneisyydestä (Kirsch 2006, 189). Kirschin kuvaus pätee myös mengenien tapauksessa.

Ihmisten työn jäljet näkyvät kaikkialla mengenien ympäristössä. Polkujen varrella olevissa puissa on alati kasvava määrä lovia, joita arkisiin askareisiinsa kulkevat kyläläiset, erityisesti nuoret miehet ja pojat, lyövät puihin viidakkoveitsillään. Tällä tavalla ei ollut poikien itsensä mukaan mitään erityistä merkitystä, mutta puissa olevat viillot auttoivat ainakin minua tunnistamaan polut, joiden löytäminen metsästä ei ollut kokemattomalle täysin itsestään selvää. Ihmisten toimintaa ei kuitenkaan nähdä vain näissä melko yhdentekevissä merkeissä, vaan mengenien metsäsanasto kattaa myös inhimillisen työn aspektin. Mengenin kielen käsite gurloon tarkoittaa yleisesti metsää, eikä sillä ole tarkempia määritteitä, joskin se kattaa neljä täsmällisempää käsitettä, jotka viittaavat metsän ikään ja käyttöasteeseen. Sana paplii voitaisiin suomentaa vesakoksi, sillä se viittaa nuoreen kasvillisuuteen, jota alkaa kasvaa metsittyvälle kaskipalstalle, eikä sitä voida vielä tässä vaiheessa raivata uudelleen. Mlaap puolestaan tarkoittaa hylätyllä kaskipalstalla kasvavaa nuorta metsää. Se eroaa papliista kasvien koon ja lajien suhteen. Kasvaessaan tietyt puut syrjäyttävät ja tappavat vesakolle tyypillisiä lajeja. Nuoressa metsässä nähdään vielä myös kaskeamisen jälkiä, kuten kantoja tai kirveen jälkiä puissa. Metsittymään jätetty palsta voidaan raivata 


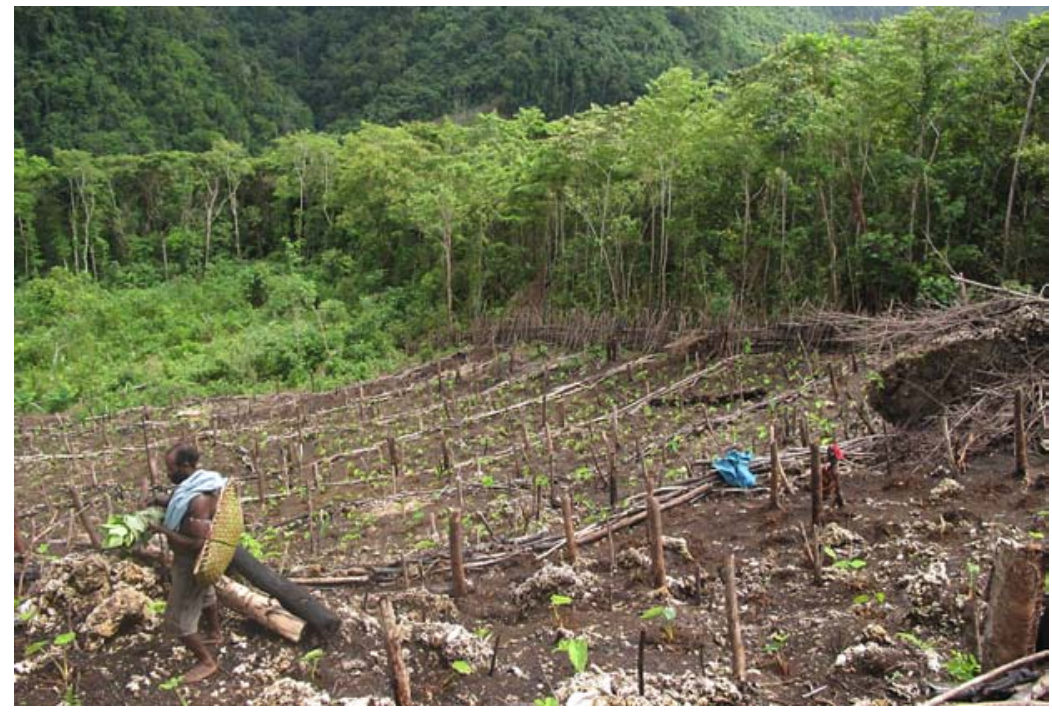

Kuva 2. Vuorenrinteellä oleva kaskipuutarha. Maahan kasatut puupinot merkitsevät yksittäisten palstojen rajoja. Puutarhan raivaaja jakaa palstat niitä viljeleville naisille erilaisten sukulaisuus- ja ystävyyssuhteiden mukaan (Tuomas Tammisto).

uudelleen noin kuuden seitsemän vuoden päästä sen hylkäämisestä. Tässä välissä paplii on muuttunut mlaapiksi. Molemmat tyypit voidaan laskea niin sanotuksi sekundäärimetsäksi.

Loom puolestaan voitaisiin suomentaa primääri- tai aarniometsäksi. Tämän tyyppistä metsää ei enää pidetä metsittyvänä kaskipalstana, vaikka informanttini olivat sitä mieltä, että mlaap voi muuttua loomiksi "erittäin pitkän ajan" kuluttua. Aarniometsä erottuu metsittyvistä kaskipalstoista puulajien ja puiden koon perusteella. Näkyvyys on aarniometsässä myös parempi harvemman aluskasvillisuuden vuoksi. Inhimillisen työn jälkiä on nähtävillä myös aarniometsässä, sillä ihmiset hakevat metsästä rakennusmateriaaleja, metsästävät siellä ja tallaavat sinne polkuja. Neljännen metsätyyppiä tarkoittavan käsitteen, loom sonin, määritelmät olivat puolestaan hieman epäselviä, mutta käsite viittaa vuorilla kasvavaan puustoltaan ja eläimistöltään aarniometsää köyhempään metsään, eikä määritelmä 
pidä sisällään näkyviä työn jälkiä. Yhden informantin mukaan loom son muuttuisi loomiksi, jos ihmiset käyttäisivät metsää, kun taas toisen mukaan ero perustui lähinnä kasvillisuuden eroihin. Olennaista on kuitenkin, että metsäsanasto painottaa ympäristön sosiaalista puolta. Kaksi ensimmäistä käsitettä viittaavat metsittyvään palstaan, aarniometsää tarkoittava käsite pitää sisällään suuren määrän inhimillistä työtä, kun taas neljäs käsite määrittyy nimenomaan sen puutteen vuoksi.

Jättämällä ympäristöön näkyviä jälkiä omasta työstään ja tällä tavoin "ankkuroimalla" itsensä maahan ovat tyypillisiä teemoja niin melanesialaisille kuin austronesialaisillekin yhteiskunnille. Esimerkiksi Maurice Bloch (1995, 65, 75) kuvaa kuinka Madagaskarilla asuvat kiertokaskiviljelijät ovat suhtautuneet metsän kaupallisiin hakkuisiin myönteisesti, koska ne ovat perinteisen työn tavoin tapa kiinnittää ihmiset maahan, joskin mittakaavaltaan perinteistä kaskeamista laajempaa — ja siten myös onnistuneempaa. Vastaavasti myös mengenien alueista pohjoiseen asuvat bainingit arvostavat suuresti työtä, joka tekee "luonnollisista" asioista sosiaalisia, esimerkiksi metsistä kaskipalstoja (Fajans 1998, 15). Tämän vuoksi myös bainingit ovat aluksi sallineet maillaan tapahtuvat hakkuut, koska ne ovat tunnistettavaa inhimillistä työtä, mutta pettyneet, kun laajamittaiset hakkuut ovat myös tuhonneet aiempia - ja bainingeille merkityksellisiä - työn jälkiä (Fajans 1998, 19, 20). Nähdäkseni myös mengenit antavat suuren arvon tällaiselle työlle, esimerkiksi viittaamalla muokattuun ympäristöön järjestettynä tai siistinä.

Jane Fajansin $(1998,14)$ mukaan bainingit tekevät luonto-kulttuuri -erottelun, mutta tämä ei ole staattinen jako. Luonto on pikemminkin "raakaa potentiaalia", jota voidaan sosiaalistaa työllä. Näin esimerkiksi sekundäärimetsä on aarniometsää sosiaalisempaa, koska sen paikalla on aikanaan ollut kaskipalsta (Fajans 1998, 15). Mengen-informanttini kertoivat, ettei mengenin kielessä ole varsinaisesti käsitteitä "villi", "kesy" tai "luonto", joskin Francoise Panoff (1969, 23) huomauttaa mengenien tekevän eron villien ja kesyjen kasvien välillä. Kesyihin eläimiin voi kuitenkin viitata käsitteellä pengee, joka 


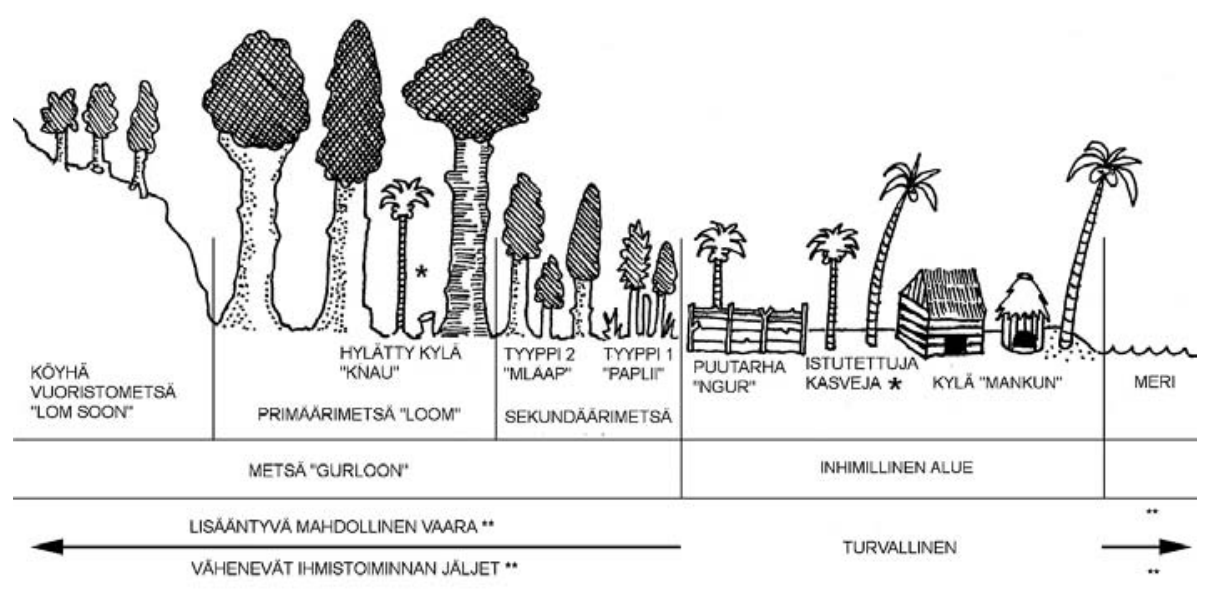

Kaavio 1: Sosiaalisuus ja aika mengenien ympäristössä (Tuomas Tammisto).

tarkoittaa laajemmin huolenpitoa (tok pisin: lukautim) ja pätee siten myös esimerkiksi adoptoituihin lapsiin. Näin ollen myös mengeneille työllä on tärkeä sosiaalistava luonne, kun esimerkiksi villit kasvit saavat sielun niitä hoidettaessa. Tämän vuoksi vaikuttaa siltä, että villi-kesy -erottelu on mengeneillekin tunnistettava, vaikka se ei olekaan yksioikoinen tai poissulkevana jaottelu. Kuten Fajans (1998, 14) huomauttaa bainingien tapauksessa, villi-kesy ei ole niinkään vastakohtapari, vaan dynaaminen suhde (ks. myös Kallisen artikkeli tässä teoksessa).

Edelliseen viitaten mengenien käsitteellinen ympäristö, eli tapa hahmottaa ympäristön eri elementtejä ja niiden keskinäisiä suhteita, voidaan mielestäni nähdä kohti ääripäitään, eli sademetsää ja merta, asteittain vähenevänä sosiaalisuutena (katso Kaavio 1).

Ihmisten työn jäljet näkyvät vielä sademetsässäkin, joka on ihmisten käyttämää ympäristöä samalla tavalla kuin meri, jossa ihmiset kalastavat ja keräävät koralleja kalkin tekemiseen. Merta ei tulisikaan nähdä niinkään rajana tai esteenä, vaan pikemminkin reittinä, jota pitkin Wide Bayn asukkaat liikkuvat. Vastaavasti metsä, kuten 
merikin, on mahdollisesti vaarallinen ympäristö, sillä metsässä voi eksyä tai joutua villisikojen hyökkäyksen kohteeksi, kun taas merellä vaarana ovat hait tai hukkuminen. Kylän ulkopuolella vaarana ovat myös noidat (tok pisin: saguma), joita mengenit kutsuvat metsien villimiehiksi. Metsä ei ole siten "tyhjää luontoa", vaan ei-inhimillistä ja villiä, mikä tekee siitä samaan aikaan vaarallisen ja hedelmällisen. Minulle esimerkiksi huomautettiin, että suoraan sademetsään raivatut palstat ovat hedelmällisimmät (ks. Bashkow 2006, 149).

Thomas Strongia (2008, henk.koht. kirjeenvaihto) mukaillen, villiin yhdistetty vaarallisuus liittynee myös sen luovaan voimaan ja Kaavio 1:n vähenevää sosiaalisuutta kuvaava akseli voidaan nähdä myös ajallisena siirtymänä. Tämä pätee monella tasolla: metsittymään jätetyt puutarhat muuttuvat ensiksi sekundääri- ja lopulta primääri- tai aarniometsäksi. Vastaavasti ihmisten töiden jäljet, eli sosiaaliset suhteiden jäljet, ovat metsässä vanhempia (esimerkiksi hylätyt kylät) ja edustavat siten menneitä suhteita tai pikemminkin suhteita menneisyyteen, kun taas kyläympäristöä leimaavat nykyiset suhteet. Myös tiettyjen myyttisten esiäitien sanotaan syntyneen metsässä olevista kasveista. Näin sademetsään liitetty hedelmällisyys ja historia yhdistyvät myös myyttisellä tasolla.

\section{Paikalliset klaanihistoriat}

Ihmisten työn jäljet ovat nähtävissä ympäristössä ja vastaavasti suuri osa metsäsanastosta kattaa myös inhimillisen työn aspektin. Näitä työn jälkiä voidaan — Stuart Kirschiä $(2006,11)$ lainaten — tarkastella yksilön elämäntarinana, joka muodostaa "liikkeiden sarjan maiseman halki". Maisema ei siten ole vain liikkumaton tausta, josta ihminen muodostaa kuvan, vaan pikemminkin ympäristö, jonka osa ihminen on. Ihminen muokkaa toiminnallaan aktiivisesti ympäristöään ja maisemassa ympäristön lukuisat eri merkitykset saavat konkreettisen muodon. Tai kuten Tim Ingold (2000, 200) asian ilmaisee, ihminen osana ympäristöään on myös osa maiseman muu- 
tosta. Käsitteinä maisema ja ympäristö ovat lähellä toisiaan, eivätkä selkeästi eroteltavissa. Kuitenkin Ingoldin (2000, 193) määritelmän mukaan maisema on ihmisten havainto ympäristöstään (huomioi tosin, ettei Ingold rajoita määritelmäänsä ihmisiin eikä näköaistiin).

Maisema rakentuu niistä merkityksistä, joita ihmiset ympäristölleen sitä havainnoidessaan antavat, eikä se siten ole absoluuttinen tai objektiivinen fyysinen "asia", vaan aina suhteessa kulttuuriseen ja historialliseen kontekstiinsa (Hirsch 1995, 1, 23). Esimerkiksi mengenien sosiaaliset suhteet ovat nähtävissä maiseman eri elementeissä, kuten metsittyvissä kaskipalstoissa. Täten yksilön elämäntarinan lisäksi maisema ja ympäristö konkretisoivat myös klaanien historioita, jotka osittain kertovat juuri liikkumisesta ympäristössä. Maisemaa voidaan pitää Kirschin $(2006,195)$ määritelmän mukaan historian aineellistumana. (Katso myös Wileniuksen artikkeli maiseman muodostumisesta Borneon kaskiviljelijöiden keskuudessa.)

Mengenien ympäristö koostuu pitkälti inhimillisen työn määrän mukaan luokitellun metsän lisäksi myös nimetyistä paikoista. Keskustellessani ympäristön eri osiin viittaavista käsitteistä ja paikkojen nimistä opin, että suuri osa niin kylän välittömässä läheisyydessä kuin myös kauempana sademetsässä olevista nimetyistä paikoista on entisiä kyliä. Itse asiassa mengenin kielessä on oma itsenäinen käsitteensä, knau, hylätylle kylälle. Kenttätyöni aikana pyrin keräämään mahdollisimman monta paikannimeä ja oppimaan niiden merkitykset. Keräämäni paikannimet jakautuvat karkeasti ottaen neljään luokkaan: nimiin, joilla ei ole tarkempaa merkitystä tai joiden merkitys on unohtunut, paikan fyysisiä piirteitä kuvaaviin nimiin, nimiin, jotka kuvaavat inhimillistä toimintaa ja nimiin, jotka viittaavat paikan fyysisten piirteiden muodostumista kuvaaviin tarinoihin.

Esimerkkeinä puhtaasti paikan piirteitä kuvaavasta nimistä on Wiakaoun, joka on hylätyn kylän nimi ja tarkoittaa villisikojen polkua, koska kylä perustettiin aikanaan paikalle, jossa villisikojen polut ristesivät. Vastaavasti moni paikannimi viittaa tiettyyn puulajiin, jota kasvaa kyseisellä paikalla runsaasti. Ihmisten toimintaa kuvaavat paikannimet viittaavat puolestaan usein melko arkisiin tapauksiin, 
kuten Wutegin, eli murtunut selkä, sillä tarinan mukaan metsästäjien kantaman elävänä pyydetyn sian selkä murtui kyseisellä paikalla. Telpuputkeis on puolestaan esimerkki paikannimestä, joka viittaa myyttiseen tarinaan paikan piirteiden muodostumisesta. Telpuputkeis, eli "mies, joka yritti kaivaa kuskusta (pussikiipijää) kivestä" on sademetsässä sijaitseva melko suuri vesiputous, jota ympäröivissä kallioissa on suuria reikiä. Tarinan mukaan pussikiipijä istui joen yllä oksalla niin, että sen varjo osui veteen. Paikalla ollut henkiolento luuli eläimen olevan vedessä ja iski varjoa kirveellään. Hän hakkasi tuloksetta reikiä kiveen yrittäessään pyytää varjoa. Lopulta paikalle tuli mies ja kysyi hengeltä miksi hän hakkaa reikiä kiviin ja tuskastunut henki ilmoitti pussikiipijän sijasta syövänsä miehen. Mies kuitenkin huomautti, että eläin istuu puun oksalla, ja kun henki katsoi sinne, mies käytti tilaisuutta hyväkseen ja pakeni. ${ }^{3}$

Paikat liittyvät tiiviisti klaanien historioihin. Klaanien historiat, tai alkuperätarinat, kertovat niiden synnystä, sukupuista, liikkeistä ja asettumisesta. Sukupuut kertovat klaanin jäsenten polveutumisen (myyttisestä) esiäidistä, kun taas liikettä ja asettumista kuvaavat tarinat kertovat missä klaanin esiäiti syntyi, minne hän meni, mitä kyliä klaanin jäsenet ovat perustaneet, minne tiettyjä jäseniä on haudattu ja minne klaanin jäsenet ovat kaskipalstojaan raivanneet. Tämän vuoksi mengenin kielen itsenäinen ilmaus hylätylle kylälle on vähemmän yllättävä. Paikat, mukaan lukien hylätyt kylät, ovat keskeisessä asemassa näissä tarinoissa. Klaanin polveutuminen sekä paikat ovat itse asiassa kietoutuneet tiiviisti toisiinsa.

James Fox (1997b, 4, 8) on osoittanut, että tämä on hyvin tyypillistä austronesialaisten kansojen keskuudessa ja kuvaa tätä ilmiötä käsitteellä topogenia, joka on - sukupuun tavoin — järjestelmällinen paikkojen nimien luettelo. Topogenia saa monia eri muotoja eri austronesialaisten kansojen keskuudessa, ja se voi kertoa myyttisten

3 Toisessa tallentamassani versiossa ei esiinny vihamielistä henkeä, vaan reiät hakkasi mies, joka ei ymmärtänyt metsästävänsä varjoa. 
esivanhempien matkoista, ryhmän liikkeistä tai jopa tietyn esineen siirtymisestä omistajalta toiselle (Fox 1997b, 9). Historia on sidottu paikkoihin, eli "topogenia edustaa muistojen ulkoistettua heijastusta” (Fox 1997b, 8). Siinä missä sukupuut kertovat polveutumisesta ajassa, topogenia kertoo siitä tilassa (Fox 1997a). Samalla tavalla kuten yksilön elämäntarina on "kirjattu” työn jäljissä ympäristöön, myös klaanien historiat ovat mengenien tapauksessa osin nähtävissä siinä. Esimerkiksi ihmiset tunnistavat hylätyt ja jo metsittyneet kylät alueella edelleen kasvavien viljelykasvien perusteella. Kuten Kirsch $(2006,189)$ toteaa, maisemassa muistot menneisyydestä aineellistuvat. Paikkojen ja historian suhde on mielenkiintoisella tavalla myös kaksi-suuntainen: yhtäältä klaanien historiat pitävät sisällään tietoa paikoista ja toisaalta paikat pitävät sisällään tai säilyttävät osia näistä historioista (Rumsey 2001, 12).

Paikkaan voidaan liittää moninaisia merkityksiä, mutta historian jäljet ovat siinä myös hyvin konkreettisella tavalla. Tämä pätee niin mengenien kaltaisten suullisten yhteiskuntien kuten myös teollisten yhteiskuntien tapauksessa. Fyysisen paikan merkitys historian aineellistumisena tulee mielestäni kiinnostavalla tavalla esille Australian ja Papua-Uuden-Guinean hallitusten välisessä sopimuksessa niin sanotun Kokoda-polun säilyttämiseksi (The National 2008). Kokoda-polku on vajaan sadan kilometrin mittainen reitti, joka kulkee Uuden-Guinean pääsaarella sijaitsevan Owen Stanley -vuoriston yli ja jota pitkin australialaiset joukot kulkivat perääntyessään japanilaisten hyökkäystä toisen maailmansodan aikana. Australian entinen konservatiivipääministeri John Howard julisti "tekevänsä mitä tahansa” estääkseen Kokoda-polun alueelle suunnitellun kultakaivoksen toteutumisen (ABC 2006). Howardin huoli hänen näkemyksensä mukaan Australian sotahistorian kannalta olennaisen alueen säilymisestä muistuttaa hyvin paljon erään vanhan sulkakansaan kuuluvan naisen huolta kaupallisten metsähakkuiden alkaessa. Hänen klaaninsa oli keskustelemassa pitäisikö klaanin mailla sallia hakkuita ja kyseinen nainen vastusti ajatusta. Hänen nuorempi klaanisisarensa kertoo: 
Perinteiset rajat ja merkit vuorella, jolla esivanhempamme asuivat, ovat vielä siellä. Kuten hautumaa ja vanhat kylät. Koska esivanhempamme olivat asettuneet tuolla vuorelle, ovat kaikki nuo asiat meille vielä siellä. Ja hän [vanhempi nainen] halusi, että myös lapset — tulevat sukupolvet - tietäisivät ne. Heidän on kyettävä näkemään nuo merkit. [oma painotukseni] - nainen, 42 vuotta

Jälkien näkyvyys on tärkeää, sillä ne ovat historian aineellisia dokumentteja. Kokodan taisteluista on kirjoitettu lukemattomia kirjoja, ja siltikin varsinainen paikka pysyy tärkeänä, kuten John Howardin huoli sen säilymisestä osoittaa. Suullisille yhteiskunnille, kuten sulka-mengeneille, näiden historiallisten merkkien säilyminen on vielä tärkeämpää. Tähän väliin on kuitenkin huomautettava, että valtaosa mengeneistä on nykyään lukutaitoisia ja klaanihistorioiden kirjaaminen on kasvattanut viime aikoina suosiotaan - ja tärkeyttään.

Kuten Michel Panoff $(1969,163)$ toteaa, klaanihistoriat muodostavat - ainakin ihanteellisesti - mengeneille yhteisesti hyväksytyn kokonaisuuden, josta asioita voidaan tarvittaessa tarkastaa. Vaikka Panoff $(1969,164,165)$ huomauttaakin, että mengenien historiat mainitsevat paikannimiä, klaanihistoriat liitetään väestön muuttoliikkeisiin ja historia on näkyvissä ympäristössä istutettujen kasvien muodossa, ei hän mielestäni silti huomaa nimenomaan paikan tärkeyttä. Paikat ja alueet ovat jotain konkreettista, johon ihmiset voivat aina palata, kuten Keith Basso $(1996,64)$ toteaa kuvatessaan apassien tiiviisti paikkoihin yhdistettyjä tarinoita. Siinä missä ajan kulku on peruuttamatonta, paikoille voi aina palata ja juuri siksi niiden avulla on hyvä ajatella. Tämä ei kuitenkaan tarkoita, että tila ja aika olisivat erillisiä ja toisistaan riippumattomia. Päinvastoin, tila koetaan aina tietyssä ajassa ja aika tilassa, minkä vuoksi historian aineellistuminen maisemassa on hyvä esimerkki tilan ja ajan tiiviistä yhteenkietoutumisesta. (Katso esim. maantieteilijä Doreen Masseyn [2008, 51] keskustelu tilan ja ajan suhteesta.)

Klaanien alkuperätarinat kertovat mengenien suhteesta ja juurtumisesta maahan. Siinä missä sukupuun pituus kertoo ryhmän suhteellisen iän, tieto paikoista on merkki ryhmän vahvasta suhteesta 


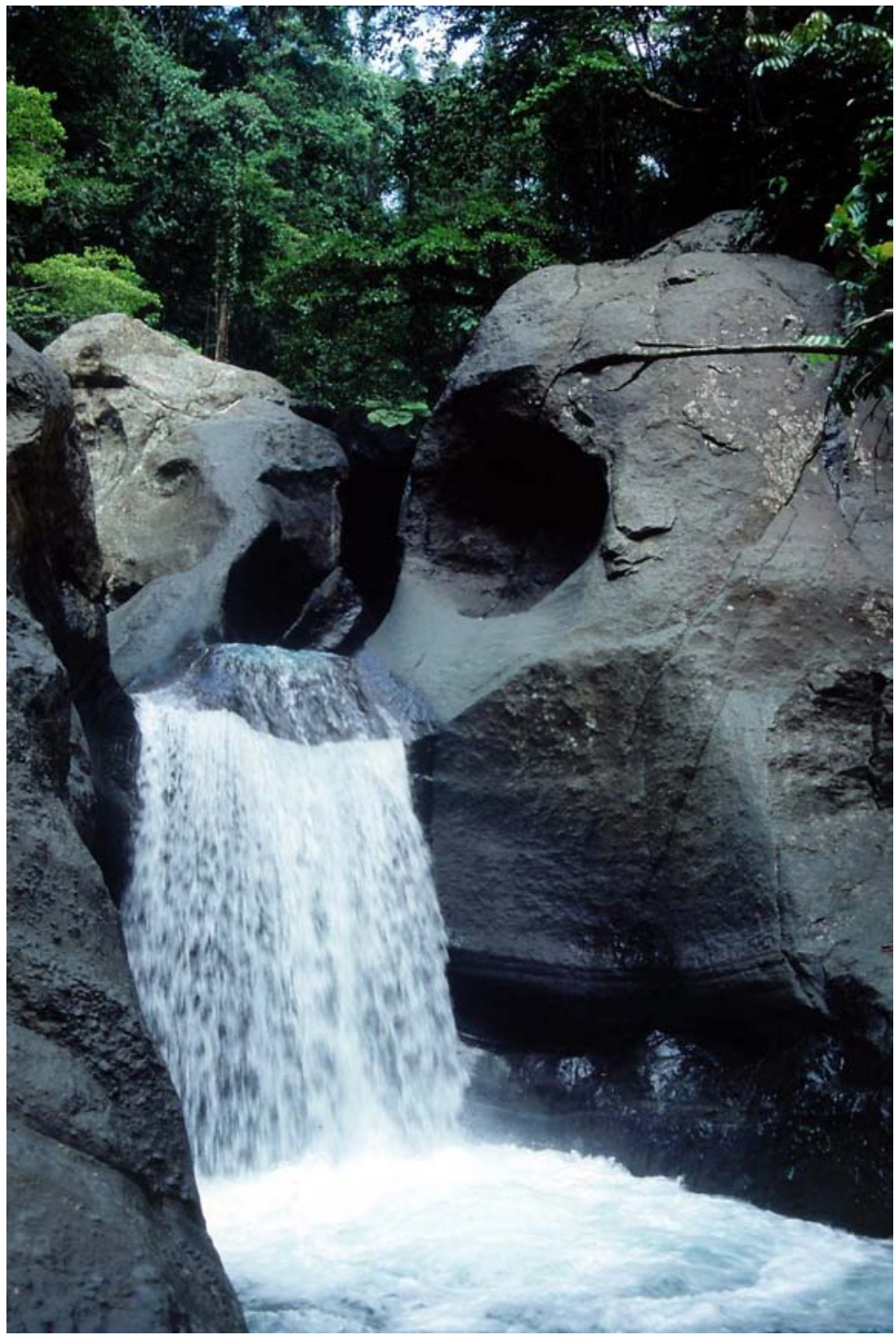

Kuva 3. Paikallistettu historia: Telpuputkeis, eli mies, joka yritti kaivaa pussikiipijää kivestä. Vesiputouksen nimi viittaa myyttiseen tarinaan, joka kuvaa paikan maastonmuotojen syntyä (Tuomas Tammisto). 
maahan. Andrew McWilliam $(1997,104)$ huomauttaa, että Länsi-Timorin (austronesialaisten) viljelijöiden keskuudessa tieto nimetyistä paikoista on yleensä ihmisillä, joilla on tiettyjä vaatimuksia maahan kyseisellä alueella. Yhteys ryhmän nimien ja merkityksellisten paikkojen välillä on maa-alueisiin kohdistuvien vaatimusten oikeuttamista (McWilliam 1997, 111). Myös sulka-mengenien keskuudessa nimettyjen paikkojen ja maanomistukseen liittyvien kysymysten suhde on merkittävä. Ryhmää (toisin sanoen klaania tai alajaostoa), joka pystyy nimeämään suurimman määrä hylättyjä kyliä, hautuumaita ja muita merkityksellisiä paikkoja tietyllä alueella, pidetään yleensä myös alueen omistajana tai hallinnoijana tilanteissa, joissa maanomistuskysymykset nousevat pintaan. Maakiistat ovat juuri tällaisia tilanteita, joissa klaanien alkuperätarinat, ja siten topogeniat, ovat uuden mielenkiinnon kohteita ja myös uusia vallan lähteitä.

\section{Hakkuut ja maakiistat}

Kyläläiset, joiden parissa tein kenttätyötä, olivat yksimielisiä siitä, että niin sanotun kehityksen, eli hakkuiden ja plantaasien, myötä maakiistojen määrä on lisääntynyt ennenkuulumattomalla tavalla. Heidän mukaansa aiemmat sukupolvet kiistelivät korkeintaan yksittäisistä kaskipalstoista, mutta eivät milloinkaan kokonaisten maaalueiden omistuksesta. Kyläläisten tärkeää huomiota tukee myös aiempi ja nykyinen tutkimus. Mengenien maankäytöstä 1960-luvulla kirjoittanut Michel Panoff (1970) ei mainitse kertaakaan maakiistoja, kun taas Keir Martin $(2007,39)$ huomauttaa, että siinä missä maakiistat olivat harvinaisia 1960-luvun Itä-Uudessa-Britanniassa, oli se 1990-luvulle tultaessa yksi johtavista Papua-Uuden-Guinean maakunnista rekisteröityjen maakiistojen määrän suhteen.

Hakkuut ja vastaavat laajamittaiset "kehitysprojektit" aiheuttavat maanomistuskiistoja, sillä ne tuovat uudella tavalla kysymyksen maan omistamisesta keskiöön. Maankäyttöoikeudet ovat perinteisesti olleet omistusta tärkeämpiä mengenien kaskitaloudessa ja 
matrilineaalisen klaanin maanomistus on pikemminkin ollut maan hallinnoimista. Vastaavasti Papua-Uuden-Guinean lainsäädännön mukaan - laskutavasta riippuen - 97-99 \% valtion pinta-alasta kuuluu kollektiivisesti niin sanotuille perinteisille omistajaryhmille (Filer \& Sekhran 1998). Perinteiset omistajaryhmät eivät ole voineet myydä maata, eikä sen yksityisomistus ole ollut mahdollista. Lainsäädännössä näitä ryhmiä kutsutaan usein klaaneiksi, mutta niitä ei ole sen tarkemmin määritelty, eikä valtio useinkaan tiedä mille tai edes minkälaiselle perinteiselle omistajaryhmälle jokin tietty alue kuuluu. Tilannetta monimutkaistaa se, ettei monilla alueilla ole perinteisesti ollut selkeitä maata omistavia klaaneja.

Vaikka sulka-mengenien tapauksessa maa on periaatteessa melko selkeiden matrilineaalisten klaanien tai niiden alajaostojen omistuksessa, ei kiistoilta vältytä. Toimiakseen lain mukaan metsäyrityksen on saatava maanomistajaryhmän lupa alueella toimimiseen ja maksettava korvauksia omistajille. Ihannetapauksissa kaikkien klaanin paikalla olevien jäsenten tulisi tehdä päätös yhdessä ja korvaukset tulisi jakaa jäsenten kesken. Mengenien klaaneilla ei ole varsinaisia johtajia, mutta yleensä vanhemmat miehet, joita pidetään hyvinä puhujina ja jotka tuntevat tarinat, toimivat klaanin edustajina. Kiistoja syntyy, sillä edes aina klaanin sisällä ei olla yhtä mieltä siitä sallitaanko hakkuita ylipäätään. Myös monimutkainen maanomistus- ja käyttöoikeusjärjestelmä tuo oman lisänsä tähän ongelmavyyhteen. Koska perinteisesti käyttöoikeudet ovat olleet omistusoikeuksia tärkeämpiä, eivät ihmiset aina tiedä mikä ryhmä on varsinaisesti omistajaryhmä ja ketkä käyttävät maata käyttöoikeuksien nojalla. On myös tärkeä huomata, että omistus ei ole poissulkevaa. Päinvastoin, omistajaan suhteessa olevat ihmiset voivat tehdä vaatimuksia hänen omistukseensa.

Maakiistojen ratkaisemiseksi on oma lainsäädäntönsä ja kiistoja voidaan ratkoa aina kylätasolta korkeimpiin oikeusasteisiin. Maakiistalainsäädännön nojalla aluehallinnot nimittävät paikallisia edustajia maakiistojen sovittelijoiksi. Maakiistan sovittelija ei voi kiistatilanteessa tehdä päätöstä, mutta jos kiistakumppanit pääsevät 
yksimielisyyteen, voi sovittelija tehdä niin sanotun kompromissisopimuksen, joka on myös laillisesti sitova. Jos maa-alueesta kiistelevät ryhmät eivät pääse sopuun, voidaan kiistoja ratkaista alueellisissa tai maakunnan oikeusistuimissa. Valtaosa haastattelemistani kyläläisistä suosi kuitenkin kylässä sopimista, koska se on halvempaa ja ennen kaikkea lopputulos on paikallisesti sovittu, eikä ulkoa käsin päätetty.

Niin kiistoja kylätasolla soviteltaessa kuin oikeudessa ratkottaessa klaanihistoriat ja sukupuut ovat keskeisessä asemassa niin sanotun perinteisen omistajaryhmän määrittämisessä. Haastattelemani paikallisen maakiistojen sovittelijan mukaan kiistoja "puntaroidessa" (tok pisin: skelim) otetaan huomioon neljä keskeistä tekijä: sukupuut, historia, asettuminen sekä klaanien väliset avioliitot. Molempien osapuolten ryhmiä pyydetään kertomaan sukupuistaan ja niiden pituutta verrataan. Pidempää sukupuuta pidetään yleensä merkkinä siitä, että ryhmä on ollut alueella pidempään. Vastaavasti koska avioliitot oman klaanin jäsenten kanssa on kiellettyjä, tutkitaan molemman klaanin solmimia avioliittoja ja pohditaan mitkä klaanit ovat saapuneet alueelle avioliiton myötä, onko jompikumpi klaaneista "vetänyt" muita avioliittojen myötä alueelleen ja niin edespäin. Kiistelevien klaanien kertomia historioita verrataan myös muiden klaanien kertomiin historioihin, jotta nähtäisiin millä versiolla on suurin yhteneväisyys muiden kertomien historioiden kanssa. Tämän vuoksi - kuten edellä todettiin - maanomistuksessa olennaista on se, että myös muut klaanit tunnustavat sen. Lopulta klaanihistorioiden ja asettumisesta kertovien tarinoiden tulisi kertoa minkä verran kiistelevät klaanit tietävät alueesta. Mitä enemmän paikkoja tietyltä alueelta pystyy nimeämään, sitä todennäköisemmin on alueen "perinteinen omistaja". Maakiistojen sovittelija muotoilee asian näin:

Jos yhdellä klaanilla on, sanotaan viisi tai kymmenen hylättyä kylää kiistanalaisella alueella ja toisella vain kaksi tai kolme - pienempi määrä esivanhempien perustamia kyliä, niin se tarkoittaa, että tämä linja [klaani] asettui alueelle vasta myöhemmin. - mies, 52 vuotta. 
Vaikka kiistojen ratkaiseminen vaihtelee alueittain erilaisten maanomistusmuotojen ja perinteiden vuoksi, on juuri alueen tuntemus keskeinen osa omistuksen määrittelyä. George Westermarck (1997, 223) huomauttaa kuinka Uuden-Guinean itäisten ylänköjen maakunnissa maakiistojen sovittelijat käyvät jopa kiistakumppanien kanssa tarkistamassa alueella olevia merkkejä vanhoista kylistä ja kaskipalstoista.

Myös ylemmissä oikeusasteissa kiistaa ratkotaan pitkälti samoin perustein kuin kylätasollakin. Kokonaisen maa-alueen omistusta koskevissa kiistoissa on usein kyse siitä mikä klaani (ja kuka klaanin sisällä) saa päättää maankäytöstä ja ketkä tulee huomioida korvauksia jaettaessa. Tällaisia hakkuiden aiheuttamia kiistoja ei voida myöskään pitää vain "paikallisina" ilmiöinä, sillä niissä osapuolina ovat usein taustalla metsäyhtiöt, jotka rahoittavat usein hakkuita kannattavia ryhmiä ja toisaalta myös kansallisia ja kansainvälisiä luonnonsuojelujärjestöjä, joilla on omat intressinsä kiistoissa. Kyse ei ole kuitenkaan vain siitä, että ulkopuoliset ja "suuret" toimijat, kuten kansalaisjärjestöt ja metsäyhtiöt, sekaantuisivat paikallisiin kiistoihin, vaan myös paikalliset pyrkivät aktiivisesti liittoutumaan eritasoisten toimijoiden kanssa. Esimerkiksi yhdessä kiistassa, jossa yksi osapuoli vastusti hakkuita ja toinen vaati alueita itselleen, myös hakkuiden kannattajat ottivat yhteyttä kansalaisjärjestöihin korostaen omaa perinteistä rooliaan alueen hallinnoijina.

Tällaisissa tapauksissa perinteiset klaanihistoriat ja alkuperätarinat politisoituvat uudella tavalla ja ovat uudenlaisen mielenkiinnon kohteina. Nykyään klaanitarinoiden ja sukupuiden kirjaaminen ylös on hyvin tavanomaista niin sulka-mengenien parissa kuin muuallakin Papua-Uudessa-Guineassa (Westermarck 1997, 218, 231). Esimerkiksi ylängöillä klaanitarinoita on alettu työstämään entisestään ja kirjoitettuja tarinoita tarjotaan oikeuteen arkistoitaviksi, jotta ne olisi kiinnitetty tulevaisuutta varten (Westermarck 1997, 230, 231). Myös mengenien parissa tarinoita on kirjattu ylös, mutta suhtautuminen tähänkin vaihtelee. Osassa tapauksia aiemmin julkisista tarinoista on tullut tarkemmin vartioituja salaisuuksia, sillä pelätään, 
että jos muut saavat tietään tarinoiden "todellisen" luonteen, he voivat muokata omia tarinoitaan paremmin tarkoitusperiään vastaaviksi. Eräs nuori ja koulutettu mies oli sitä mieltä, että tarinoiden kertominen paikallisille makkiistojen sovittelijoille oli riskialtista, sillä nämä ovat myös paikallisia omine intresseineen, mutta kiistojen sovittelijoina he kuulevat kaikkien muiden tarinat ja pystyvät näin muokkaamaan omiaan.

\section{Menetetyt paikat}

Wide Bayn asukkaat, aina omavarasviljelystä elävistä kyläläisistä paikallisiin luonnonsuojelijoihin ja hakkuita kannattaviin poliitikkoihin, ovat yhtä mieltä siitä, että rahallisia tuloja on saatava. Moni toivoo, että hakkuisiin ja plantaaseihin yhdistetty tieprojekti mahdollistaisi kauan kaivatun taloudellisen kehityksen. Hakkuut, plantaasit ja tiet eivät kuitenkaan ole yksioikoisia kysymyksiä, eivätkä alueen asukkaat missään nimessä ole yksimielisiä ehdotetun kehityshankkeen tarpeellisuudesta tai toteuttamistavasta. Päinvastoin, hakkuut ja tieprojekti ovat avoimen poliittisia kysymyksiä, jotka jakavat asukkaiden mielipiteet. Edes niin arkiselta tuntuva hanke kuin tien rakentaminen ei ole epäpoliittinen: tieverkostoa laajentamalla tiettyjä alueita voidaan sitoa tiukemmin valtion ja rahatalouden piiriin (Ferguson 1996, 253).

Ympäristö on monella tapaa merkityksellinen sulka-mengeneille. Yhtäältä ympäristöllä on tärkeitä taloudellisia merkityksiä: omavarasviljelijöille sen tila on kaskitalouden kannalta ensiarvoisen tärkeä ja vastaavasti maanomistajina ihmiset ovat tietoisia ympäristössä olevien resurssien haluttavuudesta. Toisaalta ympäristö aineellistaa merkityksellisiä sosiaalisia suhteita ja on linkki yhteisön menneisyyteen. Nämä monipuoliset kulttuuriset merkitykset eivät myöskään sanele ihmisten suhtautumista esimerkiksi hakkuisiin: metsän kaataminen ja ympäristön työstäminen ovat tunnistettavaa ja myös sosiaalisuudessaan arvokasta toimintaa kaskiviljelijöille. 
Toisaalta ihmiset ovat perustellusti huolissaan hakkuiden ja plantaasien tuomista ympäristöongelmista ja siitä, että laajamittaiset ympäristön muutokset voivat hävittää ympäristön merkityksellisiä elementtejä. Menetys voi olla hyvinkin konkreettinen kuten artikkelin alussa oleva esimerkki osoittaa. (Karina Lukin keskittyy eksymiseen ja maiseman havainnointiin tässä teoksessa olevassa artikkelissaan.)

Kenttätyöni aikana järjestettiin Papua-Uudessa-Guineassa parlamenttivaalit, ja tiehanke oli yksi vaalien keskeisistä teemoista Wide Bayn alueella. Erään kylässä järjestetyn vaalikampanjan jälkeen keskustelin tiehanketta ajavan ehdokkaan puolesta kampanjoineen mengen-miehen kanssa. Kuultuaan, että olin antropologian opiskelija, mies totesi minulle, että on hyvä, että joku on tullut tallentamaan mengenien rituaaliperinteitä, sillä tiehankkeen ja kehityksen myötä ne ovat vaarassa kadota. Jouduin tuottamaan hänelle pettymyksen kertomalla, etteivät rituaaliperinteet ole varsinaisesti tutkimukseni aihe. Hakkuita kannattavan miehen huoli kuitenkin osoittaa, että Wide Bayn asukkaille ympäristömuutosten ja kulttuurin jatkuvuuden suhde on merkittävä kysymys. Myös hakkuita vastustavat paikalliset luonnonsuojelijat olivat alkaneet tallentamaan perinteitään — nähdäkseni pitkälti samoista syistä.

Kun ympäristö aineellistaa tiettyjä kulttuurisia elementtejä, voi ympäristön muutoksellaolla huomattavia kulttuurisia seurauksia. Stuart Kirsch $(2001,174)$ kertoo kuinka Marhsall-saarilla ydinkokeiden aiheuttaman ympäristötuhon myötä kanoottien ja perinteisten kasvikuitumattojen tekoa ei enää opeteta nuoremmille polville siitä yksinkertaisesta syystä, että tarpeellisia raaka-aineita ei ole enää saatavilla. Kanootintekotaito on merkityksellistä vain käytännössä. Vastaavasti tuhotun ympäristön myötä voidaan menettää merkityksellisiä linkkejä esimerkiksi yhteisön menneisyyteen (Kirsch 2006, 189). Kulttuuri, perinteet, tieto ja taito eivät ole vain "asioita", joita ihmiset antavat eteenpäin jälkipolville, vaan käytäntöjä, joita tekemällä, aina suhteessa ympäristöönsä, kuten Tim Ingold (2000, 5, 21) on osoittanut. 
Sulkien ja mengenien osoittama huoli kulttuurinsa jatkuvuudesta on siis yhä ymmärrettävämpi. Kun kysymykset maanomistuksesta ovat hakkuiden myötä nousseet pintaan ja kun merkitykselliset paikat ympäristössä ovat myös oikeudellisia todisteita maanomistuksesta, on ympäristön tuhoamiseen sulka-mengenien tapauksessa suhtauduttava vakavuudella. Kulttuurisena lajina ihmiset eivät voi menettää kulttuuriaan, mutta he voivat menettää keskeisiä elementtejä siitä. Vaikka maanomistus onkin tärkeä seikka sulka-mengeneille, ei heidän huoltaan ympäristönsä tilasta tulisi nähdäkseni katsoa vain tältä kannalta. Kyse on laajoista kulttuurisista merkityksistä, yksilöiden ja yhteisön historiasta, joka aineellistuu ympäristössä. Mennyt aika ei palaa, mutta se säilyy paikassa, jonne voi palata ja juuri tämän vuoksi paikan avulla "on hyvä ajatella". Olettaen, ettei se muutu tunnistettamattomaksi.

\section{Lähteet}

ABC 2006. Howard Vows to Scupper Kokoda Mine. ABC The World Today 29. [www-dokumentti]

< http://www.abc.net.au/worldtoday/content/2006/s1751923.htm >. (Syyskuu 2006).

Bashkow, Ira 2006. The Meaning of Whitemen: Race and Modernity in the Orokaiva Cultural World. Chicago \& London: University of Chicago Press.

Basso, Keith H. 1996. Wisdom Sits in Places: Notes on a Western Apache Landscape. Teoksessa Steven Feld \& Keith H. Basso (toim.): Senses of Place. Santa Fe: School of American Research Press, 53-90.

Bloch, Maurice 1995. People into Places: Zafimaniry Concepts of Clarity. Teoksessa Eric Hirsch \& Michael O'Hanlon (toim.): The Anthropology of Landscape: Perspectives on Place and Space. Oxford: Clarendon Press.

Fajans, Jane 1998. Transforming Nature, Making Culture: Why the Baining are not Environmentalists. Social Analysis 42:3, 12-27.

Ferguson, James 1996. The Anti-Politics Machine: "Development", Depoliticization, and Bureaucratic Power in Lesotho. Minneapolis \& London: University of Minneapolis Press. (alkup. 1993). 
Filer, Colin \& Nikhil Sekhran 1998. Loggers, Donors and Resource Owners. Policy that Works for Forests and People No. 2: Papua New Guinea. Nottingham: Russell Press.

Fox, James 1997a. Genealogy and Topogeny: Towards an Ethnography of Rotinese Ritual Place Names. Teoksessa James Fox (toim.): The Poetic Power of Place: Comparative Perspectives on Austronesian Ideas of Locality. Canberra: ANU, 89-100.

Fox, James 1997b. Place and Landscape in Comparative Austronesian Perspective. Teoksessa James Fox (toim.): The Poetic Power of Place: Comparative Perspectives on Austronesian Ideas of Locality. Canberra: ANU, $1-22$.

Fox, James 2006. Introduction. Teoksessa James Fox \& Clifford Sather (toim.): Origins, Ancestry and Alliance: Explorations in Austronesian Ethnography. ANU E Press, 1-18. (alkup. 1996).

Gordon, Raymond (toim.) 2005. Ethnologue: Languages of the World. Fifteenth edition. Dallas, Tex.: SIL International. [www-dokumentti] $<$ http://www.ethnologue.com/show_language.asp?code=mee $>\quad$ (Elokuu 2008).

Hirsch, Eric 1995. Introduction - Landscape: Between Place and Space. Teoksessa Eric Hirsch \& Michael O’Hanlon (toim.): The Anthropology of Landscape: Perspectives on Place and Space. Oxford: Clarendon Press, $1-30$.

Ingold, Tim 2000. The Perception of the Environment: Essays in Livelihood, Dwelling and Skill. London: Routledge.

Kirsch, Stuart 2001. Lost Worlds: Environmental Disaster, "Culture Loss" and the Law. Current Anthropology 42:2, 168-198.

Kirsch, Stuart 2006. Reverse Anthropology: Indigenous Analysis of Social and Environmental Relations in New Guinea. Stanford: Stanford University Press.

McWilliam, Andrew 1997. Mapping with Metaphor: Cultural Topographies in West Timor. Teoksessa James Fox (toim.): The Poetic Power of Place: Comparative Perspectives on Austronesian Ideas of Locality. Canberra: ANU, 101-114.

Martin, Keir 2007. Land, Customary and Non-Customary in East New Britain. Teoksessa James Weiner \& Glaskin (toim.): Customary Land Tenure and Registration in Australia and Papua New Guinea: Anthropological Perspectives. ANU E Press, 39-56.

Massey, Doreen 2008. Samanaikainen tila. Suom. Janne Rovio. Tampere: Vastapaino. 
the National 2008. Kokoda to be Preserved. [www-dokumentti] < http:// www.thenational.com.pg/042408/nation2.htm >. (Luettu 24.4.2008).

Panoff, Francoise 1969. Some Facets of Maenge Horticulture. Oceania 40:1, 20-31.

Panoff, Michel 1969. The Notion of Time Among the Maenge People of New Britain. Ethnology 8:2, 153-166.

Panoff, Michel 1970. Land Tenure among the Maenge of New Britain. Oceania 40:3, 177-194.

Reesink, Ger 2005. Sulka of East New Britain: A mixture of Oceanic and Papuan traits. Oceanic Linguistics 44: 1, 145-193.

Rumsey, Allan 2001. Introduction. Teoksessa Allan Rumsey \& James Weiner (toim.): Emplaced Myth: Space, Narrative, and Knowledge in Aboriginal Australia and Papua New Guinea. Honolulu: University of Hawai' i Press, 1-18.

Westermark, George 1997. Clan Claims: Land, Law and Violence in the Papua New Guinea Eastern Highlands. Oceania 67:3, 218-233. 